\title{
Perangkat Pembelajaran berbasis Discovery Learning berbantuan Microsoft Excel untuk Meningkatkan Kemampuan Pemecahan Masalah Statistika dan Soft Skills Siswa SMP
}

\section{Ani Minarni ${ }^{1}$, E. Elvis Napitupulu² and Yaya S. Kusumah ${ }^{3}$}

\author{
1,2Jurusan Matematika, FMIPA, Universitas Negeri Medan \\ ${ }^{3}$ Departemen Pendidikan Matematika, FPMIPA, Universitas Pendidikan Indonesia \\ Corresponding Author: animinarni10@gmail.com'; elvisnapit@gmail.com² ; \\ yskusumah@upi.edu ${ }^{3}$
}

DOI: http://dx.doi.org/10.15294/kreano.v1 1i1.22494

Received : December 12 2019; Accepted: May 8 2020; Published: June 12020

\begin{abstract}
Abstrak
Penelitian ini bertujuan untuk memperoleh perangkat pembelajaran berbasis discovery learning berbantuan Microsoft Excel yang efektif dalam meningkattkan kemampuan pemecahan masalah statistika (KPMS) dan soft skills siswa SMP. Kriteria efektif bersandar pada teori intervensi pembelajaran yang meliputi adanya peningkatan capaian hasil belajar setelah intervensi, adanya respon positif siswa dan guru terhadap perangkat pembelajaran yang dikembangkan, keterlibatan (engagement) siswa yang tinggi dalam pembelajaran, serta diperoleh lebih dari $65 \%$ siswa mencapai skor 65 dari skala 100 dalam tes KPMS. Peningkatan KPMS diselidiki melalui indeks gain ternormalisasi. Peningkatan soft skills dideskripsikan dengan bersandar pada statistik deskriptik. Penelitian ini menghasilkan perangkat pembelajaran yang memiliki karakteristik efektif dalam meningkatkan KPMS dan soft skills siswa SMP sehingga siap untuk disebarluaskan. Disarankan agar guru lebih diberi kesempatan untuk mengimplementasikan perangkat pembelajaran yang dikembangkan sesuai dengan tujuan pembelajaran matematika sehingga dapat diharapkan siswa memperoleh kemampuan pemecahan masalah dan soft skills yang lebih tinggi lagi.
\end{abstract}

Kata Kunci: penelitian pengembangan; discovery learning; pemecahan masalah; soft skills

\begin{abstract}
This study aims to obtain discovery learning-based learning tools supported by Microsoft Excel that are effective in increasing statistical problem solving abilities (KPMS) and soft skills of junior high school students. Effective criteria rely on the theory of learning interventions which include an increase in learning outcomes after the intervention, positive student and teacher responses to the learning tools developed, high student engagement in learning, and obtained more than $65 \%$ of students achieving a score of 65 from a scale of 100 in the KPMS test. The increase in KPMS is investigated through a normalized gain index. Improved soft skills are described by relying on descriptive statistics. This research produces learning tools that have effective characteristics in improving problem solving skills and soft skills of junior high school students so that they are ready to be disseminated. It is recommended that teachers be given more opportunities to implement learning tools that are developed in accordance with the learning objectives of mathematics so that students can expect to get higher problem solving skills and soft skills.
\end{abstract}

Keywords: development research; discovery learning; problem solving; soft skills 


\section{PENDAHULUAN}

Menteri pendidikan dan kebudayaan Indonesia (Widjanarko, 2019) menyatakan bahwa yang menjadi prioritas pemerintah Indonesia kini adalah pembangunan sumber daya manusia yang unggul, produktif, dan mampu bersaing di kancah global. Hal tersebut menjadi tugas bidang pendidikan dengan harapan tidak ada lagi gap antara konten pendidikan dengan kebutuhan industri yang harus diselesaikan dengan link and match (keterkaitan dan kesepadanan) dan pemenuhan kebutuhan dunia real. Dunia memerlukan manusia yang mampu beradaptasi, berkolaborasi, dan memiliki kreativitas. Akan tetapi, pola pendidikan Indonesia belum banyak berubah selama 20 tahun terakhir ini, masih menekankan pada penguasaan materi sebanyak-banyaknya dan mengingat pengetahuan fakual. Di sisi lain, bukan hanya keterampilan teknis dan aspek kognitif saja sebagai kompetensi yang harus dimiliki oleh siswa sebagai produk pendidikan, tetapi juga aspek keterampilan lunak (soft skills). Hal tersebut perlu segera dibenahi sebab sering muncul keluhan dari dunia industri bahwa karyawan minim inisiatif, tak dapat bekerja dalam tim, tak percaya diri dalam mengambil keputusan, tidak komunikatif dalam mengemukakan gagasan, dan tidak disiplin waktu, dimana semua hal tersebut merupakan kunci profesionalisme.

Pernyataan Mendikbud tersebut memberi harapan pada guru sebagai aset bangsa untuk memperoleh kebebasan dalam menjalankan tugasnya sesuai dengan ide pakar pendidikan Indonesia pada masa perjuangan kemerdekaan Indonesia, Ki Hadjar Dewantara, bahwa sistem pendidikan harus bersifat kritis dan membebaskan. Ya, guru itu aset, sehingga ketika Hiroshima luluh lantak karena bom atom, maka pemimpin negaranya bertanya "berapa orang guru yang selamat?" Hal ini dikarenakan guru merupakan penggerak tumbuhnya kecerdasan dan kreativitas generasi muda bangsa yang bermartabat.

Berdasarkan uraian di atas, mau tidak mau bidang pendidikan harus selalu berubah mengikuti perkembangan zaman, terlebih lagi pada zaman revolusi industry 4.0 saat ini dimana aktivitas manusia akan serba otomatis dan dunia akan terus menerus berinteraksi dengan internet sehingga muncul slogan internet for everything (IOT) (Marr, 2018), yang jelas-jelas menuntut creative and good character people. Dibutuhkan good character sebab pada era ini berseliweran informasi (data) yang tidak hanya berguna tetapi banyak juga yang menyesatkan sehingga benar-benar dibutuhkan kejujuran dalam menggunakan data tersebut.

Selama ini, dalam beberapa laporan hasil penelitian disebutkan bahwa salah satu penyebab rendahnya hasil pendidikan adalah karena guru tidak menggunakan pendekatan pembelajaran yang berbasis konstruktivisme yang menekankan pada student-centered (Glasserfeld, 1998). Di sisi lain, penelitian juga menunjukkan bahwa guru sulit beralih dari pendekatan konvensional ataupun mendampingkannya dengan pendekatan pembelajaran lain karena mereka merasa nyaman dengan pendekatan pembelajaran konvensional (Minarni \& Napitupulu, 2017), walaupun banyak guru yang memahami bahwa the best way to learn is learning by doing sesuai dengan gagasan Bruner (Bruner, 1961).

Untuk menjadi kreatif, manusia tak boleh diam, harus doing, doing and doing. Sementara itu, to get good character (soft skills), human could learn through good education (Minarni \& Napitupulu, 2017). Kreatifitas merupakan keterampilan yang menghasilkan produk nyata. Dalam dunia pendidikan ada terminologi terkait kreatif, yaitu kemampuan berpikir kreatif. Kemampuan berpikir kreatif merupakan salah satu jenis high order thinking skills (HOTS). Maka, sudah saatnya pendidikan di Indonesia mempromosikan kompetensi tersebut. Hal ini senada dengan yang diungkap oleh the United States National Research Council, yang menyatakan bahwa HOTS penting diraih oleh siswa sekolah dasar sekalipun (Kulm, 1993; Resnick, 1987).

Meskipun sulit, tetapi HOTS dapat dikembangkan melalui pembelajaran matematika (Anisah dan Lastuti, 2018). Dalam rangka mengembangkan HOTS, Kurikulum 2013 atau K-13 menekankan tujuan dari pembelajaran matematika di sekolah pada pemahaman konsep, penalaran, pemecahkan masalah serta komunikasi matematis (Depdikbud, 2013), 
dimana kemampuan pemecahan masalah matematis didefinisikan sebagai the process of appling knowledge into new and unfamiliar situation (Anderson dan Krathwohl, 2001). Tujuan tersebut sejalan dengan standar proses bermatematika yang harus dikuasai siswa sekolah dasar hingga kelas XII yang ditetapkan National Council of Teachers of Mathematics (NCTM, 2000). HOTS related to mathematical thinking could be named as mathematical high order thingking skills (Minarni \& Napitupulu, 2019), intinya hampir sama dengan kemahiran bermatematika (mathematical proficiency) yang tertuang dalam NCTM 2000 yang meliputi kemampuan pemahaman, penalaran adaptif, dan pemecahan masalah, serta disposisi matematis. Dalam MHOTS terlibat juga kemampuan berpikir kritis dan kreatif.

Suatu hasil penelitian menyimpulkan bahwa bahwa mathematical HOTS dapat ditingkatkan melalui pembelajaran berbasis konstruktivisme (Saragih et al., 2017). Kompetensi lain yang termasuk MHOTS meliputi kemampuan pemahaman dan kemampuan representasi matematis, dan kemampuan pemecahan masalah (Minarni et al., 2016), serta kemampuan penalaran (Napitupulu, 2011) yang juga dapat dikembangkan melalui pembelajaran berbasis konstruktivisme. Jadi, untuk menilai MHOTS dapat dilakukan melalui kinerja dalam menyelesaikan masalah (problem solving skills/kemampuan pemecahan masalah matematis, disingkat KPMM).

Selain menekankan tujuan pembelajaran pada aspek kognitif, K-13 juga mendorong pengembangan aspek afektif siswa, yang meliputi sikap menghargai kegunaan matematika dalam kehidupan, memiliki rasa ingin tahu, perhatian (aware) terhadap ilmu matematika, memiliki minat mempelajari matematika, ulet dan percaya diri (self-confidence) dalam memecahkan masalah yang dihadapi, jujur, dapat dipercaya, toleran, tidak arogan, menghargai perbedaan, dapat berelasi dan berkomunikasi dengan baik. Semua komponen tersebut merupakan pembangun soft skills (John Sr., 2009).

Sebagai implikasi, guru tidak boleh melupakan perannya sebagai pembangun karakter generasi muda. Sebab, tidak ada gunanya manusia yang memiliki HOTS tinggi tetapi tidak memiliki karakter yang baik. Ini seperti pernyataan berikut: Manfaat nuklir dapat dirasakan bila berada di tangan yang bertanggungjawab pada keselamatan manusia.

Hasil penelitian menunjukkan bahwa soft skills memberi kontribusi sekitar $75 \%$ pada kesuksesan dalam pekerjaan (Sinha, 2008). Siswa Indonesia masih rendah dalam beberapa aspek soft skills seperti keterampilan sosial (Minarni, 2014), sikap positif terhadap matematika (Napitupulu, 2011), dan dalam aspek soft skills lainnya (Minarni \& Napitupulu, 2019). Dengan demikian, peran sekolah sebagai pendorong guru untuk membangun soft skills siswa semakin penting.

Melalui penelitian ini, telah dikembangkan suatu perangkat pembelajaran yang dapat memfasilitasi tercapainya KPMM untuk topik statistika, sehingga kemudian dapat disebut kemampuan pemecahan masalah statistika (KPMS). Perangkat pembelajaran ini juga dirancang untuk menumbuhkan soft skills siswa SMP. Perangakat pembelajaran ini dikembangkan berbasis discovery learning berbantuan software Microsoft excel dimana software ini sangat sesuai untuk topik statistika sebab meliputi fitur data displays dan ukuran-ukuran yang diperlukan dalam statistika. Software ikut dilibatkan dalam pembelajaran sebab siswa masa kini menyukai halhal terkait computer. Lagipula menurut Becta (2003), keterlibatan software sebagai bagian dari ICT dapat meningkatkan kolaborasi antar siswa serta mendorong komunikasi serta berbagi pengetahuan diantara mereka; memberikan umpan balik yang cepat dan akurat terhadap apa yang diperlukan siswa dan hal ini membangkitkan motivasi positif siswa; serta dapat meningkatkan hasil belajar siswa (Kusumah, 2014). Diharapkan siswa menjadi tertarik mempelajari statistika dengan lebih serius, mengetahui kehebatan dan kegunaan statistika, setidaknya memahami bahwa statistika merupakan ilmu yang diperlukan untuk menganalisis data dengan tingkat keyakinan yang diinginkan (confidence interval tertentu).

Yang menjadi subjek dalam penelitian ini adalah siswa SMP dengan pertimbangan mereka relatif lebih mudah mengalihkan kebiasaan belajar yang semula pasif menjadi 
aktif (Napitupulu et al, 2016) dan dari sisi usia telah cukup untuk diajak berpikir kritis walaupun belum setinggi kemampuan berpikir kritis siswa SMA.

Dalam penelitian ini dipilih pendekatan pembelajaran Discovery learning yang merupakan pembelajaran berbasis konstruktivisme dengan tujuan siswa menemukan sendiri pengetahuannya dengan bimbingan guru (Bruner, 1961). Dengan cara menemukan sendiri, maka pengetahuan akan bertahan lama dalam struktur kognitif siswa (Hiebert \& Carpenter, 1992). Pengetahuan seperti ini merupakan pondasi ketika siswa terlibat dalam problem solving (Minarni \& Napitupulu, 2019).

Yang menjadi pertanyaan penelitian ini adalah apakah perangkat pembelajaran berbasis discovery learning berbantuan Microsoft Excel efektif untuk meningkatkan kemampuan pemecahan masalah statistika dan soft skills siswa SMP?

\section{METODE PENELITIAN}

Penelitian ini dilaksanakan di SMP Negeri 17 Kota Medan. Penelitian dilaksanakan mulai bulan Maret hingga Juni 2019. Penelitian ini menggunakan metode penelitian pengembangan yang berorientasi pada pengembangan produk yang harus dirancang dengan teliti dan dievaluasi (Gall et al, 2003). Tujuan penelitian adalah menghasilkan perangkat pembelajaran yang memenuhi kriteria efektif dalam mencapai tujuan pembelajaran (Nieveen, 1999). Tujuan pembelajaran dalam penelitian ini meliputi: (1) Peningkatan kemampuan pemecahan masalah statistika siswa; (2) Memperoleh respon positif siswa dan guru terhadap perangkat pembelajaran yang dikembangkan; (3) Lebih dari 75\% siswa mendapat skor MPSA lebih dari 65 dari skor maksimum 100, dan rata-rata skor soft kills lebih dari 100 dari skor maksimum 160.

Peneliti lain mungkin menetapkan hal berbeda untuk tujuan pembelajaran poin ke 3. Pertimbangan peneliti menetapkan tujuan nomor 3 di sini didasarkan pada hasilhasil penelitian terdahulu yang sering sampai pada kesimpulan bahwa kemampuan pemecahan masalah matematis siswa sulit beranjak dari skor 6o (Napitupulu, 2011). Hal tersebut wajar saja mengingat kemam- puan pemecahan masalah merupakan high order thinking skills, bukan tingkatan berpikir biasa (Resnick, 1987). Lagipula, selama ini siswa selalu belajar dalam kondisi tidak terbiasa untuk memecahkan masalah nonrutin sebab pembelajaran konvensional tidak memberi peluang untuk hal tersebut (Napitupulu, 2011).

Produk penelitian ini berupa perangkat pembelajaran matematika untuk topik statistika yang telah diujicobakan pada siswa SMP, meliputi: RPP, Buku Siswa, LKS, tes KPMS, angket soft skills, pedoman wawancara, dan lembar pengamatan. Data KPMS dijaring melalui Tes I dan II, data mengenai soft skills dijaring melalui angket dimana setiap pernyataan dalam angket ini memiliki 4 pilihan pada skala Likert. Untuk menjaring respon siswa dan guru terhadap perangkat pembelajaran yang dikembangkan digunakan angket respon. Data validitas perangkat pembelajaran dijaring melalui pendapat para ahli pendidikan.

Untuk menganalisis data hasil penelitian digunakan beberapa alat statistic sebagai berikut: (1) Uji t dua arah, untuk menganalisis peningkatan KPMS dan soft skills siswa (Sudjana, 2002); (2) Descriptive statistic, untuk mendeskripsikan data angket, hasil pengamatan dan hasil wawancara; (3) Indeks gain ternormalisasi untuk menilai peningkatan KPMS siswa. Perhitungan teknis pengujian hipotesis dilakukan dengan bantuan software SPSS versi 22.0 pada taraf signifikan 0,05.

Alur penelitian ini terdiri dari tiga tahap, yaitu tahap pendefinisian, tahap perancangan, dan tahap pengembangan. Tulisan ini melaporkan hasil penelitian tahap pengembangan yang meliputi kegiatan uji coba perangkat pembelajaran pada subjek penelitian yang telah dipilih. Perangkat pembelajaran telah divalidasi oleh empat orang ahli pendidikan matematika. Dengan demikian, alur penelitian meliputi: (1) Menyelenggarakan test I KPMS; (2) Mengimplementasikan perangkat pembelajaran; (3) Menyelenggarakan test II KPMS; (4) Menyebar angket untuk menjaring respon siswa dan guru terhadap perangkat pembelajaran; (5) Menjaring data soft skills siswa.

Subjek penelitian ini adalah 30 siswa kelas VIII di SMP Negeri 17 Kota Medan, In- 
donesia. Objek penelitian adalah perangkat pembelajaran berbasis discovery learning berbantuan Microsoft Excel. Produk penelitian adalah Perangkat Pembelajaran Berbasis Discovery Learning berbantuan Microsoft Excel yang valid dan efektif dalam meningkatkan KPMS dan soft skills siswa SMP sehingga siap untuk disebarluaskan penggunaannya.

Instrumen yang dirancang adalah dua set soal KPMS, masing-masing terdiri dari 5 soal essays dengan alokasi waktu test 75 menit. Soal ini dirancang berdasarkan kriteria HOTS dari (Resni$c k, 1987)$. Sistem penilaian berpedoman pada langkah-langkah pemecahan masalah matematis dengan sedikit modifikasi dari Polya (1987) sebagai berikut: (1) Memahami masalah, diukur melalui representasi eksternal; (2) Mengajukan strategi pemecahan masalah, diukur melalui teknik yang digunakan siswa dalam menyelesaikan soal; (3) Mengeksekusi strategi yang diajukan, diukur melalui akurasi perhitungan aritmetik maupun manipulasi aljabar; (4) Merefleksi (looking back) diukur melalui kesimpulan yang diberikan siswa atas solusi yang diperoleh sesuai dengan masalah awal.

Angket yang dirancang di sini terdiri dari: Angket validasi, Angket soft skills, dan Angket respon siswa dan guru. Angket validasi terdiri dari aspek format, isi, dan bahasa yang digunakan dalam perangkat pembelajaran; angket soft skills dirancang terdiri dari 40 item pernyataan. Aspek-aspek soft skills yang diteliti meliputi kecerdasan emosional (emotional intelligence) dan kecerdasan sosial dengan aspek-aspek sebagai berikut: (1) Mengenali emosi diri; (2) Mengelola emosi; (3) Memotivasi diri sendiri; (4) Membina hubungan (relationship); (5) Menunjukkan keterampilan mengajukan pendapat.

Pedoman wawancara dirancang untuk mengungkap ketidakmampuan siswa dalam menyelesaikan soal KPMS; lembar pengamatan digunakan untuk memantau pelaksanaan pembelajaran dan keaktifan siswa di kelas.

\section{HASIL PENELITIAN}

Penelitian ini bertujuan memperoleh perangkat pembelajaran yang memiliki karakteristik yang valid dan efektif dalam meningkatkan kemampuan pemecahan masalah statistika (KPMS) dan soft skills siswa sesuai dengan yang disyaratkan (Nieveen, 1999). Kriteria valid telah dipenuhi berdasarkan hasil review yang dilakukan oleh empat ahli pendidikan matematika seperti yang disajikan pada Tabel 1.

Tabel 1. Validasi Perangkat Pembelajaran

\begin{tabular}{ccccccc}
\hline \multirow{2}{*}{ Aspek } & \multicolumn{4}{c}{ Validator } & Rata- & Kategori \\
\cline { 2 - 5 } rata & 1 & 2 & 3 & 4 & \\
\hline Format & 3,5 & 4 & 4 & 4 & 3,875 & Valid \\
Isi & 4,0 & 4 & 4 & 4 & 4 & Valid \\
Bahasa & 4,0 & 4 & 4 & 4,5 & 4,125 & Valid \\
Rata-rata & 3,833 & 4 & 4 & 4,166 & 4, & Valid \\
\hline
\end{tabular}

Perangkat pembelajaran yang dikembangkan dikatakan valid jika rata-rata skor validasi berada pada interval $0<X<4,0$. Untuk perangkat pembelajaran yang dikembangkan dalam penelitian ini diperoleh rata-rata skor validasi 4,000 seperti terlihat pada Tabel 1. Dapat disimpulkan bahwa perangkat pembelajaran ini bersifat valid.

Secara keseluruhan, kegiatan yang dilakukan dalam penelitian ini meliputi: (1) Mendeskripsikan KPMS yang diperoleh siswa, menyelidiki keterlibatan siswa dalam pembelajaran, serta soft skills siswa; (2) Menyelidiki peningkatan KPMS siswa setelah ujicoba perangkat pembelajaran berbasis discovery terintegrasi Microsoft Excel; (3) Menyelidiki peningkatan soft skills siswa; (4) Mengamati proses pembelajaran di kelas dan mencatat hal-hal penting yang terjadi selama proses pembelajaran berlangsung.

Berdasarkan keempat kegiatan tersebut dapat disimpulkan apakah perangkat pembelajaran berbasis discovery terintegrasi Microsoft Excel efektif meningkatkan KPMS dan soft skills siswa. Berikut ini deskripsi hasil penelitian secara terurut sesuai dengan yang telah dilakukan: 


\section{Deskripsi Kemampuan Pemecahan Masalah Statistika (KPMS) Siswa}

Kemampuan pemecahan masalah statistik (KPMS) siswa dapat dilihat dari hasil kerja mereka dalam menyelesaikan soal-soal KPMS. Soal-soal KPMS dirancang berdasarkan indikator-indikator kemampuan pemecahan masalah yang memenuhi karakteristik HOTS (Resnick, 1987). Indikator-indikator kemampuan pemecahan masalah diadaptasi dari Polya (1987) dan digunakan sebagai dasar pedoman penskoran kinerja siswa dalam menyelesaikan soal-soal KPMS. Pedoman ini disajikan pada Tabel 2.

Tabel 2. Pedoman Penskoran Tes KPMS

\begin{tabular}{|c|c|}
\hline Indikator & Skor \\
\hline $\begin{array}{l}\text { Dapat menyajikan masalah dalam bentuk } \\
\text { grafik/tabel/diagram/persamaan matema- } \\
\text { tis }\end{array}$ & 15 \\
\hline $\begin{array}{l}\text { Dapat menjelaskan arti data yang tertera } \\
\text { dalam grafik/tabel/diagram/persamaan } \\
\text { matematis yang diajukannya }\end{array}$ & 15 \\
\hline $\begin{array}{l}\text { Dapat menuliskan teknik/metode peny- } \\
\text { elesaian masalah sebelum melakukan per- } \\
\text { hitungan ataupun manipulasi aljabar. }\end{array}$ & 15 \\
\hline $\begin{array}{l}\text { Dapat melakukan operasi (perhitungan) } \\
\text { aritmetik dan operasi aljabar (menambah, } \\
\text { mengurang, mengalikan, membagi) ben- } \\
\text { tuk-bentuk aljabar maupun bilangan untuk } \\
\text { menyelesaikan masalah. }\end{array}$ & 25 \\
\hline $\begin{array}{l}\text { Dapat menetapkan solusi yang diperoleh } \\
\text { atau dapat menyimpulkan solusi secara ra- } \\
\text { sional sesuai dengan masalah awal }\end{array}$ & 30 \\
\hline Total skor & 100 \\
\hline
\end{tabular}

Berikut ini beberapa contoh kertas kerja beberapa siswa dalam menyelesaikan masalah KPMS setelah mereka belajar melalui pembelajaran berbasis discovery terintegrasi Micrososft Excel. Penilaian terhadap solusi masalah KPMS yang diperoleh siswa didasarkan pada pedoman penskoran dalam Tabel 2. Contoh solusi masalah yang diberikan siswa disajikan pada Gambar 1 hingga Gambar 3.

Soal nomor 2 ini telah memenuhi ciri HOTS, yaitu soal tidak dapat diselesaikan hanya dengan satu langkah, siswa perlu mencari terlebih dahulu data yang merupakan bilangan yang disyaratkan sebelum menentukan rata-rata data tersebut. Soal ini juga menuntut pemahaman siswa atas konsep bilangan prima. Jadi, cukup menantang untuk diselesaikan. Jawaban siswa A untuk soal ini tersaji pada Gambar 1.a; Siswa A menunjukkan bahwa ia telah mampu memahami masalah soal nomor 2 karena telah dapat menuliskan bilangan prima antara o dan 30 dengan benar sesuai yang diminta soal. la juga dapat menuliskan konsep untuk menentukan ratarata dari suatu data, dan ini dapat dipandang sebagai strategi untuk menyelesaikan masalah. Eksekusi terhadap strategi yang diajukan juga benar, yaitu menunjukkan pemahaman atas notasi sigma; hasil akhir yang diperolehnya benar. Dapat dilihat bahwa ketika pemahaman siswa atas masalah telah benar maka hal tersebut menjadi modal awal bagi langkah penyelesaian masalah selanjutnya. Hal ini sesuai dengan hasil penelitian yang dilakukan

Soal 2: Tentukanlah rata-rata bilangan prima antara o dan 30.

$\begin{aligned} & \text { (2.) bilangan diantora } 0-30:\{2,3,5,7,11,13,17,19,23,29\} \\ & \bar{x}=\sum x / n \\ &=2+3+5+7,11,13,17,19,23,29 / 10 \\ &=129 / 10 \\ &=12,9\end{aligned}$

Gambar 1.a. Contoh Penyelesaian Soal Nomor 2 dari Siswa A

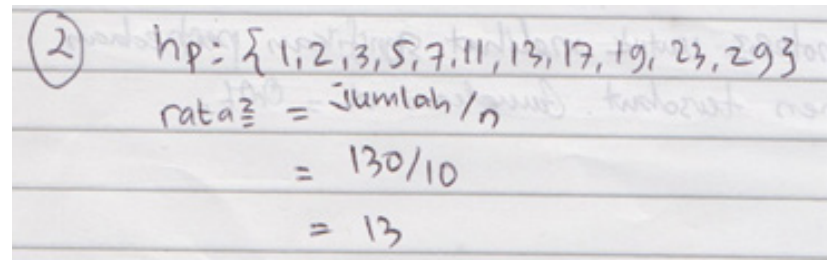

Gambar 1.b. Contoh Penyelesaian Soal Nomor 2 dari Siswa B 
peneliti yang menyatakan bahwa kemampuan pemahaman merupakan pondasi bagi penyelesaian masalah (Minarni et al., 2016). Meskipun dia tidak sampai kepada penulisan kesimpulan, namun secara keseluruhan langkah-langkah pemecahan masalah hingga solusi yang diperolehnya adalah benar.

Siswa B pada Gambar 1 mengalami masalah pemahaman konsep, ia salah dalam mengajukan bilangan prima, seharusnya 1 tidak termasuk bilangan prima sebab secara konsep bilangan prima adalah bilangan lebih dari 1 dan hanya dapat dibagi oleh 1 dan dirinya sendiri. Jadi seharusnya dimulai dari bilangan 2. Hasil penelitian menunjukkan memang masih ada siswa yang mengalami kesulitan pada bagian pemahaman konsep. Hal ini mungkin dikarenakan terbatasnya waktu penelitian sehingga konsep yang dipelajari masih sulit bagi sebagian siswa karena mereka memiliki kecepatan belajar berbeda. Gambar 2 berikut ini menyajikan solusi soal nomor 4 .

Soal 4: Tentukanlah varians dari data berikut, lalu simpulkan hasilnya.

\begin{tabular}{|l|l|l|l|l|}
\hline 4 & 5 & 4 & 3 & 2 \\
\hline 2 & 3 & 2 & 5 & 1 \\
\hline
\end{tabular}

Solusi:

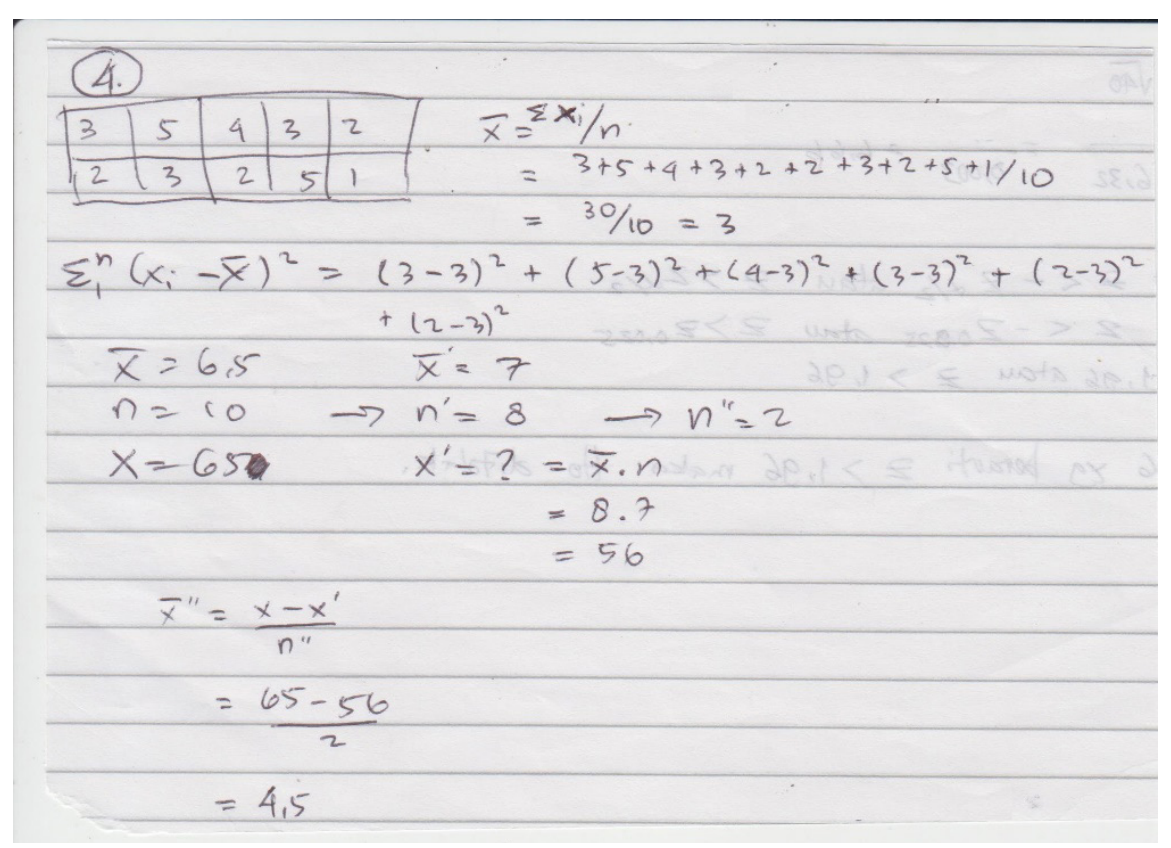

Gambar 2. Contoh Penyelesaian Soal Nomor 4 Dari Siswa C

Solusi masalah nomor 4 yang diajukan siswa $C$ pada Gambar 2 belum sampai pada jawaban akhir, baru sampai pada menjalankan teknik pemecahan masalah. Kemudian, dia sudah beralih ke soal nomor lainnya, yaitu soal menentukan rata-rata baru ketika data bertambah dimana rata-rata data lama diketahui. Sayangnya dia tidak memberi nomor pada pekerjaannya tersebut sehingga guru hanya menebak bahwa itu adalah solusi untuk soal nomor 5. Dan walaupun teknik penyelesaian masalah yang diajukan berbeda dari yang telah disepakati tetapi teknik tersebut secara konsep benar dan menghasilkan solusi yang benar untuk soal nomor 5 . Ini yang disebut strategi heuristic dalam pemecahan masalah (Polya, 1987).

Solusi soal nomor 4 yang diberikan siswa $C$ telah memenuhi empat indikator kemampuan pemecahan masalah matematis terkait topik statistika, yaitu kemampuan memahami, kemampuan mencari informasi yang tidak diketahui untuk menyelesaikan soal melalui rumus rata-rata sebagai alat untuk mencarinya, mengajukan rumus varians sampel dengan benar, melakukan perhitungan, hingga diperoleh solusi akhir. Indikator yang tidak dipenuhinya adalah menyimpulkan solusi yang 


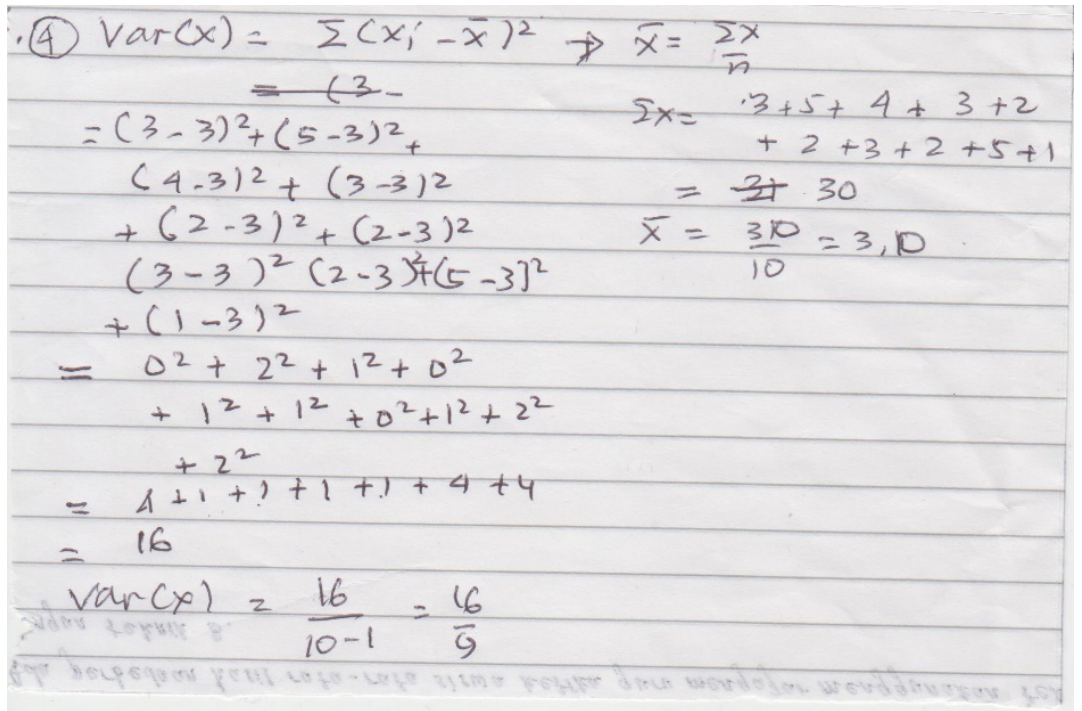

Gambar 3. Contoh Penyelesaian Soal Nomor 4 dari Siswa D

diperoleh sesuai dengan tuntutan soal, tetapi indicator ini adalah pilihan lain untuk indicator menetapkan solusi. Jadi, secara keseluruhan kinerja siswa ini dalam menyelesaikan masalah statistika telah benar. Observer menyatakan bahwa siswa ini telah benar-benar belajar dan mendapat manfaat dari scaffolding yang diberikan guru. Dengan demikian wajar jika dia mampu menerapkan pengetahuan yang diperolehnya ke dalam masalah yang baru dihadapinya. Menurut Anderson, kemampuan ini merupakan kemampuan problem solving, yaitu the ability to apply knowledge into unfamiliar/new problem (Depdikbud, 2013).

Berdasarkan hasil penilaian terhadap kertas kerja seluruh siswa yang terlibat dalam penelitian ini, secara keseluruhan sudah menunjukkan kemampuan pemecahan masalah statistik yang tertuang dalam solusi masalah KPMS yang diberikan siswa. Hanya ada sebagian kecil siswa yang masih mengalami kesulitan dalam menyelesaikan soal KPMS meskipun mereka telah mendapat pembelajaran berbasis discovery terintegrasi ICT.

Kesulitan-kesulitan tersebut terletak pada aspek-aspek sebagai berikut: Aspek pemahaman. Masih terdapat siswa yang belum mampu menyatakan masalah ke dalam bentuk persamaan matematis, gambar ataupun grafik. Ada juga siswa yang masih belum paham konsep bilangan prima, seperti terlihat dalam penyelesaian soal tes I nomor 2 (Gambar 1); Aspek memilih strategi pemecahan masalah. Siswa yang mengalami kesulitan dalam menetapkan strategi pemecahan masalah terlihat dari penulisan teknik/strategi yang salah. Misalnya, ketika akan membuat tabel distribusi frekuensi, siswa tidak menuliskan aturan untuk menetapkan banyaknya interval kelas ataupun panjang kelas untuk membuat tabel tersebut, tetapi asal saja dalam menetapkannya padahal telah didiskusikan dalam proses pemebelajaran; Aspek menjalankan strategi pemecahan masalah. Menjalankan strategi dapat dilihat melalui proses perhitungan maupun manipulasi aljabar. Contoh solusi masalah dengan kesalahan seperti ini dapat dilihat pada Gambar 2, siswa B; Aspek merefleksi. Siswa yang mengalami kesulitan dalam melakukan refleksi dapat dilihat pada Gambar 2 dan Gambar 3, yang menyajikan solusi masalah tes I nomor 4 .

\section{Deskripsi Keterlibatan (engagement) Siswa dalam Pembelajaran}

Data keterlibatan siswa dalam pembelajaran diperoleh dari hasil observasi yang dilakukan observer. Hasilnya disajikan pada Tabel 3.

Pada Tabel 3 terlihat bahwa setiap komponen keterlibatan siswa dalam pembelajaran di atas $85 \%$ dengan rata-rata 90, 275 sehingga dapat disimpulkan bahwa keterlibatan (engagement) siswa di kelas cukup tinggi. Rasional untuk temuan ini adalah karena sintaks pembelajaran discovery memungkinkan siswa 
Tabel 3. Data Hasil Observasi terhadap Aktivitas Siswa di Kelas

\begin{tabular}{lccc}
\hline \multirow{2}{*}{ Keaktifan siswa dalam diskusi kelas dan diskusi kelompok } & \multicolumn{2}{c}{ \% Hasil Pengamatan } \\
\cline { 2 - 4 } & Aktif & $\begin{array}{c}\text { Kurang } \\
\text { Aktif }\end{array}$ & $\begin{array}{c}\text { Tidak } \\
\text { aktif }\end{array}$ \\
\hline Berbagi ide dengan teman sekelompok saat diskusi kelompok & 96,6 & 0 & 3,4 \\
Berbagi ide dengan teman saat diskusi kelas & 93,3 & 6,7 & 0 \\
Bertanya pada guru/kelompok lain ketika kelompoknya tidak dapat & 90 & 10 & 0 \\
menyelesaikan masalah & 86,7 & 13,3 & 0 \\
Bertanya pada guru saat diskusi kelas & 86,7 & 0 & 13,3 \\
Mengemukakan pendapat berbeda saat diskusi kelompok & 90 & 10 & 0 \\
Mengemukakan pendapat berbeda saat diskusi kelas & 93,3 & 6,7 & 0 \\
Menjawab pertanyaan guru atau teman saat diskusi kelas & 86,7 & 0 & 13,3 \\
Mengemukakan saran pada saat diskusi kelas & 93,3 & 6,7 & 0 \\
Mencermati pekerjaan kelompok lain saat disajikan & 86,7 & 13,3 & 0 \\
Mencoba memecahkan masalah dengan cara lain & 90 & 10 & 0 \\
Mengajukan pertanyaan yang bersifat memelukan penjelasan & 90 & 10 & 0 \\
Mengajukan pertanyaan yang bersifat konfirmasi & 90,275 & 7,225 & 2,5 \\
\hline Rata-rata & 3,1475 & 4,6729 & 4,9188 \\
\hline Standar deviasi
\end{tabular}

Keterangan: Banyak siswa = 30. Kriteria Aktif: jika sebagian besar siswa (> 75\%) aktif dalam diskusi kelompok atau diskusi kelas; Kurang aktif: jika sekitar 25\% - 75\% siswa aktif dalam diskusi kelompok atau diskusi kelas, selain itu Tidak aktif: jika kurang dari $25 \%$ siswa yang aktif dalam diskusi kelompok atau diskusi kelas

membentuk karakter berani untuk bersuara mengemukan masalah yang dihadapi dan mengajukan pendapatnya sendiri untuk menyelesaikannya (Depdikbud, 2013). Dan yang paling utama adalah soal-soal KPMS yang telah dirancang dan disajikan dalam LKS dapat mendorong siswa bekerja kooperatif dan kolaboratif dalam menyelesaikan masalah matematis terkait topik statistika yang dihadapinya. Dengan demikian, sebaiknya guru menjaga agar keterlibatan siswa dalam pembelajaran, khususnya dalam memecahkan masalah statistik maupun masalah matematis lainnya tetap tinggi.

\section{Peningkatan Kemampuan Pemeca- han Masalah Statistik (KPMS)}

Peningkatan KPMS dianalisis melalui uji signifikansi perbedaan skor tes KPMS I dan II. Pengujian dilakukan menggunakan uji $\mathrm{t}$ (Sudjana, 2002). Deskripsi data skor tes I dan tes II KPMS siswa disajikan pada Tabel 4.

Tabel 4. Deskripsi Tes I dan Tes II KPMS

\begin{tabular}{cccc}
\hline Tipe & N & Mean & $\begin{array}{c}\text { Standar } \\
\text { deviasi }\end{array}$ \\
\hline Tes I & 30 & 10,33 & 1,493 \\
Tes II & 30 & 15,03 & 2,282 \\
\hline
\end{tabular}

Dari Tabel 4 dapat diperoleh selisih ratarata skor KPMS I dan II adalah 4,70 dari skor total maksimum 20. Ini berarti terjadi peningkatan sebesar $23,5 \%$. Uji signifikansi peberbedaan rata-rata tersebut dilakukan melalui uji t. Hasilnya disajikan pada Tabel 5 .

Table 5. Independent samples t-test for KPMS

\begin{tabular}{ccccc}
\hline$T$ & Df & Sig. & Mean diff. & Std. error diff. \\
\hline 9,441 & 58 & .000 & 4,70 & 0.498 \\
\hline
\end{tabular}

Berdasarkan Tabel 5, diperoleh selisih skor antara tes KPMS I dan II adalah 4,70, maka dapat disimpulkan bahwa implementasi pembelajaran berbasis discovery terintegrasi Microsoft Excel dapat meningkatkan kemampuan pemecahan masalah statistik siswa. Ini dapat dipahami, mengingat pendekatan discovery merupakan salah satu pendekatan pembelajaran berbasis konstruktivisme yang memungkinkan siswa membangun pengetahuan bagi dirinya (Glassergeld, 1998) dan pengetahuan tersebut menjadi mudah untuk dipanggil dari struktur kognitif siswa ketika memecahkan masalah. Rata-rata gain ternormalisasi untuk skor KPMS disajikan pada Tabel 6. 
Tabel 6. Deskripsi skor Tes I, Tes II, dan Indeks Gain Ternormalisasi KPMS

\begin{tabular}{cccc}
\hline Tipe & Tes I & Tes II & Gain \\
\hline Rata-rata & 10,33333 & 15,03333 & 0,486 \\
Simp. Baku & 1,468181 & $\mathbf{2 , 2 4 3 2 6 2}$ & 0,0418 \\
\hline
\end{tabular}

Nampak pada Tabel 6 bahwa rata-rata indeks gain ternormalisasi untuk data KPMS adalah 0,486 dengan simpangan baku 0,0418. Indeks ini tergolong dalam kategori sedang (Arikunto, 2013). Peningkatan KPMS dimungkinkan terjadi sebab selama program pembelajaran materi statistika, siswa terus menerus didorong untuk menyelesaikan masalah statistika non-rutin yang menuntut mereka untuk mengeluarkan kemampuan pemahaman, penalaran, dan kemampuan representasi sehingga ketiga kemampuan tersebut menjadi terasah. Dengan memiliki ketiga kemampuan tersebut akan memudahkan siswa untuk menyelesaikan masalah (Minarni et al., 2016; Napitupulu, 2011). Selama proses pembelajaran, penyelesaian masalah yang dilakukan siswa secara manual langsung dibandingkan dengan hasil yang diperoleh melalui penggunaan Microsoft Excel. Menurut guru observer, siswa nampak gembira ketika hasil yang mereka peroleh secara manual sama dengan hasil yang diperoleh melalui penggunaan software. Hal ini menambah semangat mereka untuk mengerjakan soa-soal lainnya dalam LKS.

Selain itu, sintaks discovery learning yang mengharuskan siswa untuk melakukan investigasi, dapat memperkaya pengetahuan siswa dan pengetahuan tersebut dapat tersimpan dalam jangka waktu lama dalam memori siswa karena pengetahuan tersebut merupakan hasil investigasi sendiri. Ketika pengetahuan tersimpan dalam jangka waktu lama maka dapat memudahkan untuk digunakan pada saat memecahkan masalah lainnya. Sintaks discovery learning lainnya adalah kegiatan pengajuan hipotesis (dugaan sementara) atas jawaban terhadap masalah, kemudian diikuti oleh kegiatan membuktikan dugaan melalui pemecahan masalah.

Tahapan-tahapan tersebut disertai berlangsung dengan scaffolding yang benar dan terarah dari guru sehingga dapat meningkatkan kemampuan pemecahan masalah matematis/statistik siswa. Kemampuan pemecahan masalah merupakan salah satu kemampuan berpikir tingkat tinggi, menurut Saragih dkk., kemampuan berpikir tingkat tinggi dapat ditingkatkan melalui pembelajaran yang berpusat pada siswa (Saragih, dkk., 2017).

Hasil wawancaran dan angket juga menunjukkan bahwa implementasi perangkat pembelajaran berbasis discovery terintegrasi Microsoft Excel membuat siswa tertarik dan termotivasi untuk menyelesaikan masalahmasalah statistik yang diberikan dalam LKS. Penelitian lain juga menunjukkan bahwa keterlibatan ICT, dimana Microsoft Excel merupakan salah satu unsur ICT, membuat siswa tertarik untuk belajar dan banyak memberi manfaat yang antara lain membuat siswa aktif, energik, kreatif, teliti, dan konsentrasi dalam belajar (Becta, 2003).

\section{Peningkatan Soft skills Siswa}

Peningkatan soft skills siswa dianalisis melalui uji beda dua rata-rata menggunakan statistik uji t pada taraf signifikansi 0,05 dengan tipe uji dua arah (Sudjana, 2002). Deskripsi soft skills siswa disajikan pada Table 7.

Tabel 7. Deskripsi Soft skills Siswa

\begin{tabular}{cccc}
\hline Tahap & N & Rata-rata & Standar Deviasi \\
\hline 1 & 30 & 91,43 & 8,406 \\
2 & 30 & 117,43 & 6,841 \\
\hline
\end{tabular}

Dapat dilihat pada Tabel 7 bahwa skor soft skills siswa pada pengisian angket yang ke-2 yaitu setelah selesai pelaksanaan pembelajaran menggunakan pendekatan discovery terintegrasi Microsoft Excel, telah meningkat dibanding skor angket tahap 1. Hasil uji signifikansi perbedaan rata-ratanya disajikan pada Tabel 8.

Table 8. Independent samples t-test for Soft skills

\begin{tabular}{ccccc}
\hline $\mathrm{T}$ & Df & $\begin{array}{c}\text { Sig.two } \\
\text { tailed }\end{array}$ & $\begin{array}{c}\text { Mean } \\
\text { diff. }\end{array}$ & $\begin{array}{c}\text { Std. error } \\
\text { diff. }\end{array}$ \\
\hline 13.139 & 58 & .000 & 26.000 & 1.979 \\
\hline
\end{tabular}

Berdasarkan Tabel 8 dapat disimpulkan bahwa perbedaan rata-rata skor soft skills siswa ternyata signifikan (nilai sig. two tailed o,00o). Dengan demikian, dapat dinyatakan bahwa perangkat pembelajaran berbasis dis- 
covery terintegrasi Microsoft Excel berpengaruh signifikan terhadap soft skills siswa. Tahap melaksanakan investigasi pada pembelajaran discovery membuat siswa sabar dan ulet dimana kedua karakter ini merupakan komponen-komponen soft skills (John, Sr., 2009). Indeks gain ternormalisasi untuk data soft skills disajikan pada Tabel 9 .

Tabel 9. Deskripsi skor Tes I, Tes II, dan Indeks Gain Ternormalisasi Soft skills

\begin{tabular}{cccc}
\hline Tipe & Tes I & Tes II & Gain \\
\hline Rata-rata & 91,433 & 117,433 & 0,372 \\
Simp. Baku & 8,2651 & 6,7265 & 0,1171 \\
\hline
\end{tabular}

Nampak pada Tabel 9 perolehan ratarata indeks gain ternormalisasi adalah 0,371. Indeks tersebut masih berada pada kategori sedang. Dapat dimengerti mengapa implementasi perangkat pembelajaran berbasis discovery terintegrasi ICT dapat meningkatkan KPMS maupun soft skills siswa, hal tersebut dikarenakan discovery learning sendiri memiliki fitur yang memungkinkan siswa menyerap dan memahami pengetahuan yang dipelajarinya secara mendalam. Gain tersebut kemungkinan besar masih dapat ditingkatkan dengan melibatkan subjek penelitian dalam jumlah yang lebih besar. Fitur discovery learning yang dijalankan di kelas penelitian ini telah sesuai dengan yang ditetapkan sintaks discovery learning (Depdikbud, 2013), meliputi: (1) Guru memberikan stimulus yang menimbulkan konflik kognitif pada siswa. Konflik kognitif dapat terjadi ketika hasil kerja siswa secara manual berbeda dengan hasil yang diperoleh Microsoft Excel. Adanya konflik kognitif menimbulkan rasa ingin tahu siswa untuk mengetahui kebenaran; (2) Guru mendorong siswa untuk membuat problem statement, yaitu menuliskan pertanyaan yang diajukan dalam soal. Fase ini mendorong siswa untuk bernalar memahami masalah rumit yang diajukan kepadanya; (3) Guru memotivasi siswa untuk melaksanakan pengumpulan data yang diperlukan untuk memecahkan masalah (data collecting), sebagai contoh mencari data hilang dalam tabel distribusi frekuensi ketika rata-rata data diketahui; (4) Memandu siswa untuk melakukan data processing. Pada fase ini, terjadi pembentukan konsep yang dipa- hami siswa. Dengan arahan dari guru, konsep yang terbentuk diarahkan ke bentuk konsep yang benar; (5) Verifikasi. Pada tahap ini siswa diberi kesempatan untuk membuktikan hasil yang diperoleh dari data processing. Dengan adanya proses ini, konsep yang diperoleh siswa dapat diingat siswa dalam jangka waktu panjang dalam long-term memory mereka; (6) Generalisasi, berdasarkan solusi yang dihasilkan beberapa soal terkait konsep yang sama, siswa dipandu guru untuk menetapkan aturan umum (prinsip).

Keenam tahapan tersebut sebagian besar dijalankan siswa pada setiap kali menyelesaikan masalah statistik. Data pendukung tentang hal ini dapat dilihat pada hasil observasi keterlaksanaan pembelajaran di kelas (Tabel 10). Siswa juga semakin tertarik dan tertantang menyelesaikan masalah-masalah statistik karena adanya bantuan Microsoft Excel. Sebab dengan bantuan software tersebut, sajian data menjadi beragam sehingga semakin akurat dan menarik. Dengan demikian dapat dipahami jika terjadi peningkatan kemampuan pemecahan masalah matematis setelah implementasi perangkat pembelajaran discovery terintegrasi Microsoft Excel.

\section{Proses Pembelajaran di Kelas}

Keterlaksanaan proses pembelajaran di kelas merupakan salah satu syarat agar perangkat pembelajaran yang dikembangkan memiliki kategori praktis, kategori lainnya adalah valid dan efektif (Nieveen, 1999). Data keterlaksanaan pembelajaran yang dijalankan oleh guru diperoleh melalui observasi, hasilnya disajikan pada Tabel 10.a. s.d. 10.f.

Berdasarkan data pada Tabel 10, diperoleh rata-rata jawaban "ya" adalah 87,495 dengan simpangan baku 8,6177. Ini berarti guru telah melaksanakan lebih dari $87 \%$ sintaks pembelajaran berbasis discovery terintegrasi Microsoft Excel. Persentase tersebut telah memenuhi salah satu syarat efektivitas perangkat pembelajaran (Nieveen, 1999). Memang, tidak setiap selesai mengerjakan soal guru mengajak siswa melakukan refleksi (melihat apakah ada cara lain untuk menyelesaikan masalah) dikarenakan keterbatasan waktu. Demikian juga, tidak setiap selesai mengerjakan soal guru mengajak siswa mem- 
Tabel 10.a. Keterlaksanaan Pembelajaran di Kelas

\begin{tabular}{lccc}
\hline \multicolumn{1}{c}{ Komponen yang Diobservasi (Stimulasi) } & \multicolumn{2}{c}{ \% Jawaban } \\
\cline { 2 - 4 } & Ya & TJ & Tidak \\
\hline Guru membuka pelajaran dengan memberikan masalah aktual terkait kehidupan siswa. & 100 & 0 & 0 \\
Guru mengajak siswa menyelesaikan masalah-masalah yang ada pada LKS & 91,67 & 0 & 8,33 \\
Guru mampu menunjukkan masalah yang ada dalam LKS menimbulkan konflik & 75 & 0 & 25 \\
kognitif pada siswa & &
\end{tabular}

Tabel 10.b. Keterlaksanaan Pembelajaran di Kelas

\begin{tabular}{lccc}
\hline \multirow{2}{*}{ Komponen yang Diobservasi (Problem Statement) } & \multicolumn{2}{c}{ \% Jawaban } \\
\cline { 2 - 4 } & Ya & TJ & Tidak \\
\hline Guru mendorong siswa untuk menyelidiki masalah yang ada dalam soal. & 91,67 & 0 & 8,33 \\
Guru mendorong siswa untuk menuliskan informasi yang ada dalam soal & 100 & 0 & 0 \\
Guru mendorong siswa untuk mencatat informasi yang perlu dicari untuk me- & 91,7 & 0 & 8,3 \\
nyelesaikan soal &
\end{tabular}

Keterangan: TJ=Tidak Jelas

Tabel 10.c. Keterlaksanaan Pembelajaran di Kelas

\begin{tabular}{lccc}
\hline \multicolumn{1}{c}{ Komponen yang Diobservasi (Data Collecting) } & \multicolumn{2}{c}{ \% Jawaban } \\
\cline { 2 - 4 } & Ya & TJ & Tidak \\
\hline Guru memotivasi siswa untuk mencari data/informasi yang diperlukan untuk & 83,3 & 0 & 16,7 \\
menyelesaikan soal & & 16,7 \\
Guru memberikan informasi tentang sumber pengetahuan yang dapat digunakan & 83,3 & 0 & 1,6 \\
Guru memandu siswa untuk memilih informasi yang diperlukan & 91,67 & 0 & 8,33 \\
\hline Keterangan:TJ-Tidak Jelas & &
\end{tabular}
Keterangan: TJ=Tidak Jelas

Tabel 10.d. Keterlaksanaan Pembelajaran di Kelas

\begin{tabular}{lccc}
\hline \multicolumn{1}{c}{ Komponen yang Diobservasi (Data Processing) } & \multicolumn{2}{c}{ \% Jawaban } \\
\cline { 2 - 4 } & Ya & TJ & Tidak \\
\hline Guru mengkondisikan siswa untuk siap melakukan pengolahan data & 100 & 0 & 0 \\
Guru meminta siswa menyajikan data dalam bentuk yang tabel, diagram, grafik & 91,67 & 0 & 8,33 \\
$\begin{array}{l}\text { Guru mendorong siswa bekerja sama dalam kelompok untuk menentukan rata- } \\
\text { rata, median, modus dari data yang diperoleh }\end{array}$ & 83,3 & 0 & 16,7 \\
$\begin{array}{l}\text { Guru meminta siswa menentukan varians dan standar deviasi bagi data yang di- } \\
\text { peroleh siswa }\end{array}$ & 100 & 0 & 0 \\
$\begin{array}{l}\text { Guru memperkenalkan Microsoft Excel pada siswa } \\
\text { Guru mengajak siswa menentukan ukuran pemusatan data maupun ukuran se- } \\
\text { baran data menggunakan Microsoft Excel } \\
\text { Guru meminta siswa membandingkan solusi yang diperoleh secara manual den- } \\
\text { gan yang menggunakan Microsoft Excel. }\end{array}$ & 91,76 & 0 & 8,33 \\
\hline
\end{tabular}

Keterangan: TJ=Tidak Jelas

Tabel 10.e. Keterlaksanaan Pembelajaran di Kelas

\begin{tabular}{lccc}
\hline \multicolumn{1}{c}{ Komponen yang Diobservasi (Verifikasi) } & \multicolumn{2}{c}{ \% Jawaban } \\
\cline { 2 - 4 } & Ya & TJ & Tidak \\
\hline Guru mengajak siswa untuk melakukan pembuktian atas rata-rata, median, mo- & 75 & 0 & 25 \\
dus yang diperoleh siswa & & \\
Guru mengajak siswa untuk menggunakan rumus varians dan standar deviasi & 83,3 & 0 & 16,7 \\
pada masalah lainnya. & 91,7 & 0 & 8,3 \\
\hline Guru menilai proses dan hasil akhir & &
\end{tabular}

Keterangan: TJ=Tidak Jelas

\section{UNNES JOURNALS}


Tabel 10.f. Keterlaksanaan Pembelajaran di Kelas

\begin{tabular}{lccc}
\hline \multicolumn{1}{c}{ Komponen yang Diobservasi (Generalisasi) } & \multicolumn{2}{c}{ \% Jawaban } \\
\cline { 2 - 4 } & Ya & TJ & Tidak \\
\hline Guru mengajak siswa meninjau kembali apa yang telah dikerjakan & 75 & 0 & 25 \\
Guru mengajak siswa melihat apakah ada cara lain penyelesaian masalah & 75 & 0 & 25 \\
Guru mengajak siswa untuk menentukan rumus umum rata-rata-rata, median, & 75 & 0 & 25 \\
modus, varians, dan standar deviasi & & & \\
\hline
\end{tabular}

Tabel 10.g. Rangkuman

\begin{tabular}{cccc}
\hline \multirow{2}{*}{ Statistik Total } & \multicolumn{3}{c}{ \% Jawaban } \\
\cline { 2 - 4 } & Ya & TJ & Tidak \\
\hline Rata-rata & 87,495 & 0 & 13,340 \\
Simpangan baku & 8,6177 & 0 & 8,5023 \\
\hline
\end{tabular}

Catatan: $100 \%$ = seluruh item dipenuhi sepanjang program pembelajaran (12 item soal dalam LKS)

buat generalisasi atas solusi yang diperoleh, sebab generalisasi dapat dilakukan setelah ada lebih dari dua kasus penyelesaian soal. Tetapi jika sebaiknya tetap menyempatkan diri memandu siswa merangkum bahan/materi setelah selesai pembelajaran agar yang tertanam dalam struktur kognitif siswa adalah pengetahuan yang benar (tepat). Berdasarkan hasil pengamatan, secara keseluruhan guru telah melaksanakan pembelajaran dengan baik. Data hasil angket mengenai respon siswa dan guru terhadap perangkat pembelajaran disajikan pada Tabel 11.

Dapat dilihat pada Tabel 11 bahwa rata- rata respon positif siswa dan guru di atas $85 \%$. Dengan demikian, perangkat pembelajaran yang dikembangkan ini menurut hasil angket respon telah memenuhi kriteria respon positif (Minarni \& Napitupulu, 2017). Lebih lanjut, observasi terhadap keterlaksanaan pembelajaran di kelas telah memenuhi kriteria praktis, artinya pembelajaran dapat dilaksanakan dengan tidak terlalu terkendala oleh waktu yang tersedia. Kemudian, hasil analisis juga menunjukkan bahwa: (1) implementasi perangkat pembelajaran ini dapat meningkatkan kemampuan pemecahan masalah matematis dan soft skills siswa; (2) Respon siswa

Tabel 11. Respon Siswa dan Guru Terhadap Komponen-komponen Perangkat Pembelajaran

\begin{tabular}{lcc}
\hline \multicolumn{1}{c}{ Pernyataan } & $\%$ Respon Positif \\
\cline { 2 - 3 } & Guru & Siswa \\
\hline Saya menyukai tampilan materi pelajaran statistika ini & 87,5 & 96,7 \\
Saya menyukai isi dan sistematika KLS & 87,5 & 93,3 \\
Saya menyukai suasana belajar secara berkelompok & 100 & 86,7 \\
Saya menyukai soal-soal dalam LKS & 87,5 & 86,7 \\
Saya menyukai buku siswa topik statistika & 87,5 & 90 \\
Saya menyukai petunjuk penggunaan software Excel & 87,5 & 100 \\
Soal-soal dalam LKS menarik dan menantang untuk dikerjakan & 100 & 90 \\
Soal-soal dalam buku siswa menuntut saya untuk berpikir keras & 87,5 & 100 \\
Soal-soal dalam LKS menuntut untuk membuat tabel, diagram, grafik & 75 & 90 \\
Saya menyukai pernyataan-pernyataan dalam angket soft skills & 75 & 86,7 \\
Kegiatan pembelajaran membuat siswa terbiasa membuat kesimpulan & 87,5 & 93,3 \\
Tahapan belajar membuat siswa terbiasa membuat problem statement & 75 & 90 \\
Soal-soal dalam LKS menuntun siswa untuk membuat penjelasan terhadap solusi & 87,5 & 96,7 \\
Soal-soal dalam LKS menuntun siswa untuk membuat generalisasi & 87,5 & 93,3 \\
Bantuan Microsoft Excel membantu meningkatkan kejelasan diagram, grafik, ta- & 100 & 100 \\
bel untuk data dari soal. & 8 & 30 \\
N & 87,5 & 92,893 \\
Rata-rata & 7,9 & 4,687 \\
Simpangan baku &
\end{tabular}


dan guru terhadap perangkat pembelajaran bersifat positif; (3) Skor KPMS individu maupun kelompok telah mencapai skor minimum yang telah ditetapkan, yaitu 65, (4) Keterlibatan (engagement) siswa dalam pembelajaran cukup tinggi. Hasil tersebut merupakan karakteristik efektivitas perangkat pembelajaran yang dikembangkan. Dengan demikian, perangkat pembelajaran berbasis discovery terintegrasi Microsoft Excel telah memiliki karakteristik valid, praktis, dan efektif dalam meningkatkan kemampuan pemecahan masalah statistic siswa SMP.

\section{PENUTUP}

\section{Simpulan}

Berdasarkan penjelasan di atas, simpulannya adalah sebagai berikut: (1) Berdasarkan hasil analisis data maka dapat disimpulkan bahwa perangkat pembelajaran berbasis discovery learning terintegrasi Microsoft Excel bersifat valid, praktis, dan efektif untuk meningkatkan kemampuan pemecahan masalah statistik dan soft skills siswa SMP. Hal tersebut disimpulkan berdasarkan adanya peningkatan hasil belajar (kemampuan pemecahan masalah statistik dan soft skills), respon positif guru dan siswa terhadap perangkat pembelajaran, keterlaksanaan pembelajaran di kelas, dan aktivitas aktif (engagement) siswa dalam proses pembelajaran; (2) Kemampuan pemecahan masalah matematis meningkat dengan kategori rata-rata indeks gain sedang, demikian juga soft skills; (3) Perangkat pembelajaran berbasis discovery learning terintegrasi Microsoft Excel siap untuk diserbarluaskan (disseminate) untuk meningkatkan kemampuan pemecahan masalah statistik dan soft skills siswa SMP; (4) Masih terdapat sebagian kecil siswa yang mengalami kesulitan dalam setiap komponen kemampuan pemecahan masalah statistik, tetapi secara keseluruhan mereka telah meraih kemampuan pemecahan masalah secara signifikan; dan (5) Komponen soft skills yang masih perlu mendapat perhatian lebih adalah komponen membina relationship dan keterampilan menyatakan pendapat.

\section{Saran}

Berdasarkan hasil penelitian ini, disarankan agar: (1) Guru lebih diberi kesempatan untuk mengimplementasikan perangkat pembelajaran yang dikembangkan sesuai dengan tujuan pembelajaran matematika sehingga dapat diharapkan siswa memperoleh kemampuan pemecahan masalah dan soft skills yang lebih tinggi lagi; (2) Guru tetap menjalankan perannya sebagai pemberi scaffolding, tidak hanya memberikan pengetahuan statistika dalam bentuk yang sudah jadi; (3) Guru menyempatkan diri untuk memandu siswa menyimpulkan bahan yang dipelajari setelah selesai pembelajaran sehingga yang tertanam dalam kognitif siswa adalah pengetahuan yang tepat. Melalui kegiatan ini diharapkan siswa yang lambat belajar dapat memahami materi yang belum dipahami sepenuhnya sehingga dapat meningkatkan kapabilitas mereka dalam penguasaan komponen-komponen pemecahan masalah yang masih lemah.

\section{UCAPAN TERIMAKASIH}

Ucapan terimakasih yang sebesarbesarnya disampaikan kepada Kemenristek Dikti yang telah memberi dana untuk pelaksanaan penelitian ini.

\section{DAFTAR PUSTAKA}

Anderson, L.W. \& Krathwohl, D.,R. (2001). A Taxonomy for Learning, Teaching, and Assessing. New York: Addison Wesley Longman, Inc.

Anisah \& Lastuti, S. (2018). Pengembangan Bahan Ajar berbasis HOTS untuk Meningkatkan Kemampuan Pemecahan Masalah Matematis Mahasiswa. Kreano-Jurnal Matematika Kreatif Inovatif, 9(2), 191-197.

Arikunto, S. (2013). Prosedur Penelitian: Suatu Pendekatan Praktik. Jakarta: Rineka Cipta.

Becta (2003). What the Research Says about ICT and Motivation. Available online at www. Becta.org.uk/ research.

Bruner, J. S. (1961). The Act of Discovery. Harvard Educational Review, 31, 21-32.

Depdikbud (2013). Kurikulum 2013. Jakarta: Depdikbud. Gall, M.D., Gall, J.P. \& Borg, W.R. (2003). Educational Research. Boston: Pearson Education, Inc.

Glasersfeld, E. von (1998). Why constructivism must be radical. In: Larochelle M., Bednarz N. \& Garrison J. (eds.) Constructivism in Education. Cambridge University Press, New York NY: 23-28.

Hiebert, J. \& Carpenter, T.P., (1992). Learning and Teaching with Understanding. Dalam D.A. Grouws 
(Ed). Handbook of research on mathematics teaching and learning: A project of the National Council of Teachers of Mathematics. (pp. 65-97). New York, NY, England: Macmillan Publishing Co, Inc.

John Sr, J. (2009). Study on the Nature of Impact of Soft skills Training Programme on the Soft skills Development of Management Students. Pacific Business Review, pp. 19-27.

Kulm, G. (1993). Assessing high order thinking in mathematics. Washington, D.C.: American Association for the Advancement of Science.

Kusumah, Y. (2014). Model pembelajaran matematika berbasis ICT untuk meningkatkan kemampuan matematis siswa. Seminar nasional pendidikan matematika, P4TK Yogyakarta pada Tanggal 28 November 2014.

Marr, B. (2018). Why Everyone Must Get Ready For The fourth Industrial Revolution. Forbes. Retrieved 14 February 2018.

Minarni, A. (2014). Pengaruh Pembelajaran Berbasis Masalah terhadap Kemampuan Pemahaman Matematis dan Keterampilan Sosial Siswa SMP Negeri di Kota Bandung. Jurnal Pendidikan Matematika PARADIKMA, 6(2), 162-174

Minarni, A. \& Napitupulu, E. E. (2017). Developing Instruction Materials Based on Joyful PBL to Improve Students Mathematical Representation Ability. International Education Studies, 10(9), 23-38.

Minarni, A. \& Napitupulu, E. E. (2019). Learning Approach and Soft skills Contribution toward Mathematical Higher Order Thinking Skills of Junior High School Students. American Journal of Educational Research, 7(12), 925-929.

Minarni, A., Napitupulu, E.E., Husein, R. (2016). Mathematical Understanding and Representation Abil- ity of Public Junior High School in North Sumatera. IndoMS Journal on Mathematics Education, 7(1), 45-56.

Napitupulu, E., E. (2011). Pengaruh Pembelajaran Berbasis Masalah terhadap Kemampuan Penalaran, Pemecahan Masalah Matematis, dan Sikap Siswa terhadap Matematika. (Doctoral Dissertation). Bandung: PPs UPI. (Tidak Diterbitkan).

Napitupulu, E. E. (2016). Cultivating Upper Secondary Students' Mathematical Reasoning Ability and Attitude towards Mathematics through Problem-Based Learning. IndoMS Journal of Mathematics Education (JME IndoMS), 7(2), 117-128.

NCTM, (2000). Principle and Standards for School Mathematics. Reston: VA.

Nieveen, N. (1999). Prototype to reach product quality. Dalam Van den Akker, J., Branch, R.M., Gustafson, K., Nieveen, N., \& Plomp, T. (Eds.). Design Approaches and Tools in Educational and Training. Dordrecht: Kluwer Academic Publisher.

Polya, G. (1987). Mathematical Discovery: Combined Edition. New York: John Wiley Interscience.

Resnick, L. B. (1987). Education and Learning to Think. Washington, DC: National Academy Press. p. $\underline{8}$. ISBN 0309037859 .

Saragih, S., Napitupulu, E. E., \& Fauzi, A. (2017). Developing Learning Model Based on Local Culture and Instrument for Mathematical Higher Order Thinking Ability. International Education Studies, 10(06), 114-122.

Sinha, M. P. (2008). Minding Our MBA Manners. Competition Success Review: ghrdc.org/ articles/ Minding Our MBA Manners \& MBA Education.

Sudjana. (2002). Metoda Statistika. Bandung: Tarsito.

Widjanarko, B. (2019). Menanti "Kuda Troya" Nadiem. Harian Kompas, 16 Desember 2019. 